\title{
THE INDUCTION OF GROSS MYOCARDIAL LESIONS BY A COXSACKIE (PLEURODYNIA) VIRUS AND CORTISONE ${ }^{1,2}$
}

\author{
BY EDWIN D. KILBOURNE, ${ }^{3}$ CHARLES B. WILSON, AND DOROTHY PERRIER \\ (From the Division of Infectious Disease, Dept. of Medicine, Tulane University School of \\ Medicine, New Orleans, La.)
}

(Submitted for publication July 5, 1955 ; accepted December 12, 1955)

Coxsackie viruses are defined by their virulence for infant mice and hamsters and their inability to induce manifest disease in adults of these species. It has been shown that the administration of cortisone to the adult mouse changes this state of intrinsic resistance to one of marked susceptibility resulting in death (1). This dramatic effect is brought about only with those strains of Group $B$ (pleurodynia) Coxsackie virus which can multiply to some extent in the adult mouse in the absence of cortisone (2). Infection of normal adult mice with Group $B$ viruses, types 1 and 3, results in non-fatal disease associated with pathologic changes largely confined to the pancreas $(3,4)$. The administration of cortisone results in prolonged viremia and persistence of virus in the lung and brain (4).

In the present investigation efforts had been made to effect a lethal adaptation of a strain of Group B, type 3 virus to the adult mouse by serial passage in the cortisone-injected host. The virus employed was recovered directly in cortisoneinjected adult mice from the stool of a patient with epidemic pleurodynia, without intervening passage in infant mice. On the 11 th passage, gross necrotic lesions of the myocardium were discovered. The nature and pathogenesis of these lesions are the subject of this paper.

\section{MATERIALS AND METHODS}

$V$ irus-A virus (1302) recovered from a pleurodynia patient's stool in New Jersey in 1950 by the senior author was used in most experiments. The line of virus designated "infant mouse virus" was recovered from the

\footnotetext{
1 This investigation was supported in part by a grant from the Life Insurance Medical Research Fund.

2 A preliminary report of this work was presented before the Central Society for Clinical Research on October 30, 1953.

8 Present address: Department of Public Health and Preventive Medicine, Cornell University Medical College, New York, N. Y.
}

same stool and passed exclusively in infant mice by intraperitoneal inoculation of whole carcass suspensions. The history of the adult mouse strain is detailed in Table I. We are indebted to Dr. Gilbert Dalldorf for his classification of this agent as a Group B, type 3 Coxsackie virus. The Conn. 5 strain of Group B, type 1 virus and another Group B, type 3 strain supplied by Dr. Dalldorf were employed in one experiment. Both strains had previously been passed only in infant mice.

Antibiotics-Viral suspensions were inoculated in 0.5cc. volumes which included final concentrations of 10 units of penicillin and $1 \mathrm{mg}$. of streptomycin per cc. Control saline injections also included both antibiotics.

Cortisone-Cortisone was administered in the form of Cortone (Merck) in 1 to 5 -mg. dosage subcutaneously. Control mice received the suspending agent used in this preparation.

Mice-Sixteen to twenty $\mathrm{Gm}$. male CFW mice were used in all experiments. Infant mice were of the same strain and were less than 48 hours old when inoculated.

Infectivity titrations-Infectivity titrations in adult mice were effected by the intraperitoneal injection of 0.5 -cc. amounts of virus dilutions in groups of four mice concomitantly given $5 \mathrm{mg}$. of cortisone subcutaneously. $\mathrm{LD}_{50}$ was calculated in the usual manner. Mice were observed for 10 days.

Scoring of lesions-A quantitative estimation of the extent of gross myocardial necrosis was made according to the following scoring system: lesions involving 10 per cent or less of the myocardial surface, $1 ; 10$ to 30 per cent, $2 ; 30$ to 50 per cent, $3 ;>50$ per cent, 4 . The cumulative score of a group of mice was determined by the formula $\frac{(n \times 1)+(n \times 2)}{\text { total } n \times 4}$ etc., when $n \times 4=\operatorname{maxi}$ mum possible score.

Preparation of immune serum-Specific immune serum against the 1302 strain was produced by intraperitoneal injection of thirty 25 to $30-\mathrm{Gm}$. adult mice with $0.5 \mathrm{cc}$. of a $10^{-2}$ No. 2 Coor's filtrate of suckling mouse suspension containing infective virus. After 21 days mice were bled from the heart and sera pooled.

Histologic examination-Tissues were fixed in Bouin's solution for one hour. Paraffin block sections were stained with hematoxylin and eosin.

Tissue cultures-Hela cell cultures were obtained as tubes of monolayer cultures from Microbiological Associates, Inc. Monolayer monkey kidney cultures were obtained through the courtesy of Dr. Henry Gelfand from the laboratory of Dr. John P. Fox. 
RESULTS

\section{Adaptation of 1302 virus to adult mice}

In the sense of selecting or inducing mutation of a viral variant lethal for the adult mouse, adaptation has not been accomplished. However, study of Table I will demonstrate that a measure of adaptation to the cortisone-injected mouse has been effected as indicated by the greater extent of myocardial necrosis in later passages. Passage without cortisone resulted in multiplication of virus in the myocardium, but no gross myocardial disease (passages 18-21, Table I).

\section{The occurrence of gross myocardial lesions}

The first ten viral passages were effected by brain suspensions until cardiac lesions were noted, by chance, on the 11th passage. Subsequently, the 15 th to 22 nd passages were made with heart suspensions after myocardial lesions were consistently observed in passages 12 to 14 . The grossly evident lesions are illustrated in Figure 1. Microscopic examination (Figure 3) defined these lesions as large areas of necrosis characterized by degenerating muscle fibers showing fragmentation, cytoplasmic granularity or "smudging," and frequently, increased basophilia. Many of the degenerating fibers were anuclear or had pyknotic nuclei. Fragments of nuclear debris were frequently seen scattered through the areas of necrosis. There was a mild to moderate degree of infiltration of the areas of necrosis by large and
TA BLE I

Serial passage of 1302 virus in cortisone-injected adult mice *

\begin{tabular}{|c|c|c|c|c|c|}
\hline Passage & $\begin{array}{l}\text { Virus } \\
\text { source }\end{array}$ & Dilution $\dagger$ & $\begin{array}{l}\text { Inoc. } \\
\text { route }\end{array}$ & $\begin{array}{c}\text { Cortisone } \\
\text { dose }\end{array}$ & $\begin{array}{l}\text { Cardiac } \\
\text { lesions }\end{array}$ \\
\hline & & & & $m g$. & \\
\hline 1 & Stool & 1.0 & i.c. & 5 & $\ddagger$ \\
\hline 2 & Brain & 2.3 & i.p. & 5 & $\S$ \\
\hline 3 & Brain & 5.0 & i.p. & 5 & $\S$ \\
\hline 4 & Brain & 2.0 & i.p. & 5 & $\ddagger$ \\
\hline 5 & Brain & 1.3 & i.p. & 5 & \\
\hline 6 & Brain & 2.0 & i.p. & 5 & $\S$ \\
\hline 7 & Brain & 2.0 & i.p. & 5 & $\S$ \\
\hline 8 & Brain & 2.0 & i.p. & 1 & 8 \\
\hline 9 & Brain & 2.0 & i.p. & 1 & 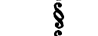 \\
\hline 10 & Brain & 2.0 & i.c. & 1 & \\
\hline 11 & Brain & 2.0 & i.p. & 1 & \\
\hline 12 & Brain & 2.0 & i.p. & 1 & \\
\hline 13 & Brain & 2.0 & i.p. & 5 & \\
\hline 14 & Brain & 2.3 & i.p. & 5 & \\
\hline 15 & Heart & 2.0 & i.p. & 5 & \\
\hline 16 & Heart & 2.0 & i.p. & 5 & \\
\hline 17 & Brain & 2.0 & i.p. & 5 & $\mathbb{\|}$ \\
\hline 18 & Heart & 2.0 & i.p. & 0 & II \\
\hline 19 & Heart & 2.0 & i.p. & 0 & Iี \\
\hline 20 & Heart & 2.0 & i.p. & 0 & I \\
\hline 21 & Heart & 2.0 & i.p. & 0 & बा \\
\hline 22 & Heart & 2.0 & i.p. & 5 & $\|$ \\
\hline
\end{tabular}

* Cortisone dosage was reduced in passages 8-12 in an effort to assess the degree of adaptation of the virus. Induction of lethal disease in all animals was not effected by the lower dose, so that the original dosage regimen was resumed.

$t$ Log of dilution.

‡ Small areas of necrosis and cellular infiltration evident on microscopy of repetitions of this passage.

$\$$ Hearts not examined for lesions.

II Grossly apparent cardiac lesions.

ه Cardiac lesions not grossly apparent.

small mononuclear cells, and in many instances, polymorphonuclear leukocytes were noted scattered throughout the infiltrate. ${ }^{4}$

4 The authors are indebted to Dr. Alan Rabson for his assistance in the interpretation of tissue sections.

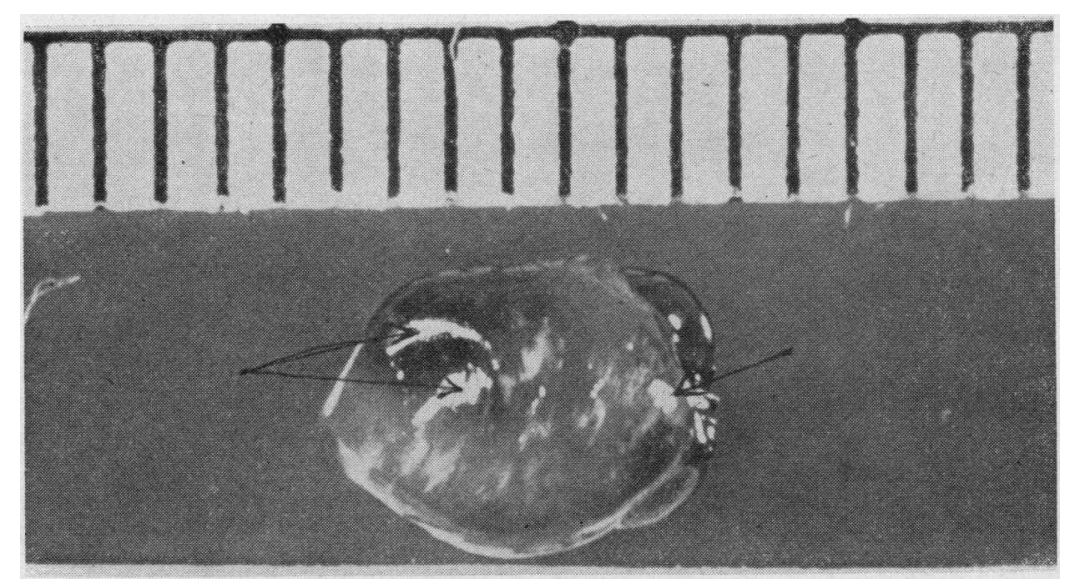

Fig. 1. Gross Lesions Induced by Virus and Cortisone

(Scale in millimeters.) Arrows indicate high lights. 


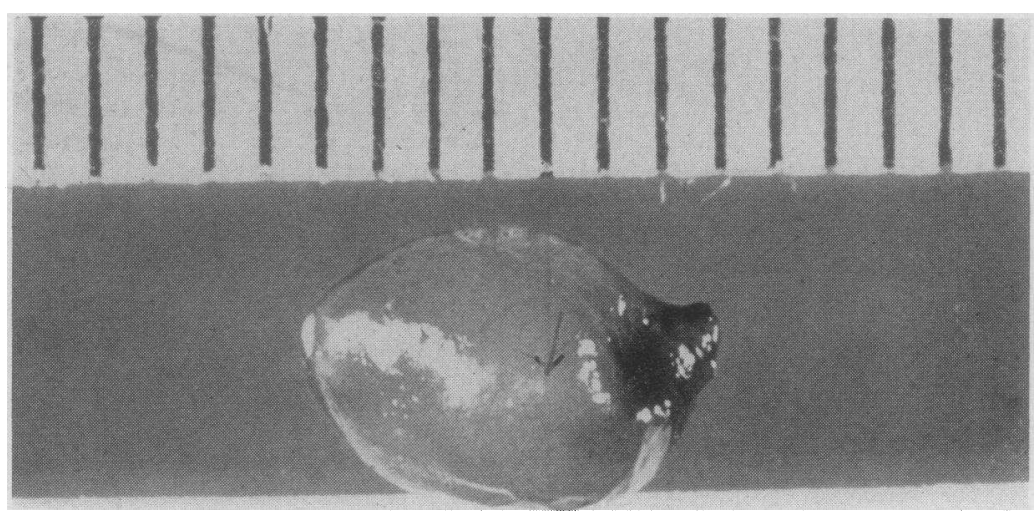

Fig. 2. Gross Lesions Associated with Cortisone Injection Alone (ARRow)

The large white area on the left is an artifact of light reflection (high light).

Myocardial lesions in control mice injected with cortisone

The sporadic occurrence of tiny but grossly evident heart lesions in mice given cortisone alone (Figure 2) prompted section and microscopic examination of these hearts. As is demonstrated in Figure 4, the predominant lesion in grossly damaged hearts was found to be a coagulation necrosis with minimal cellular infiltration which was frequently associated with periarteritis. However, section of hearts without gross necrosis from cortisone-injected animals revealed only focal necrosis and infrequent evidence of vasculitis and

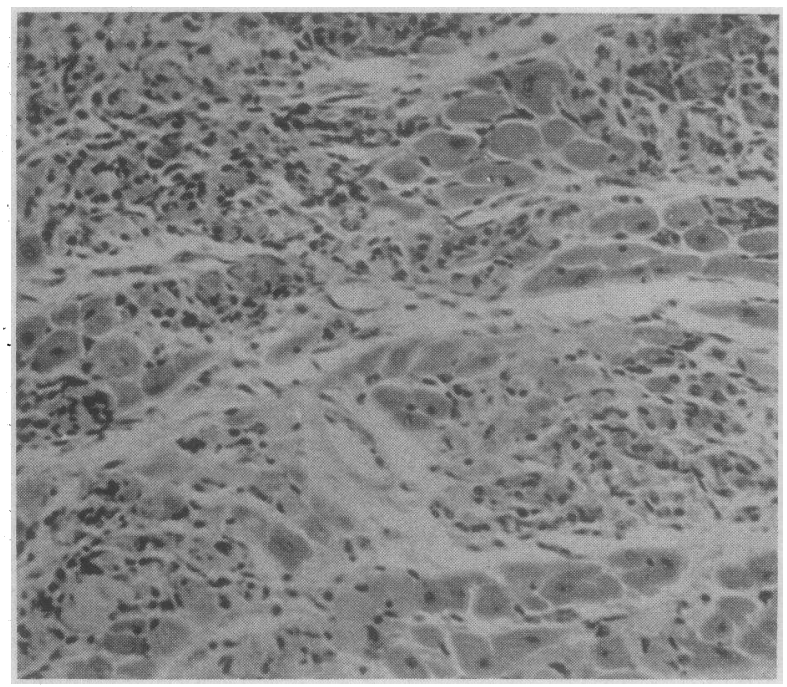

Fig. 3. Myocardial Necrosis Induced by Virus and Cortisone valvulitis. Evidence that the cortisone lesions differ from those associated with administration of virus, or virus plus cortisone, is summarized in Table II. The sharply focal nature of the necrosis and inconstant occurrence of gross lesions together with their lack of transmissibility are arguments against their identity with Coxsackie virus-related lesions. Lesions associated with cortisone alone appeared to differ as well from previously described "spontaneous" murine carditis $(5,6)$. It is of interest that gross cardiac lesions were reported in 17 per cent of rats given large amounts of cortisone acetate (7). The nature of these lesions was not defined.

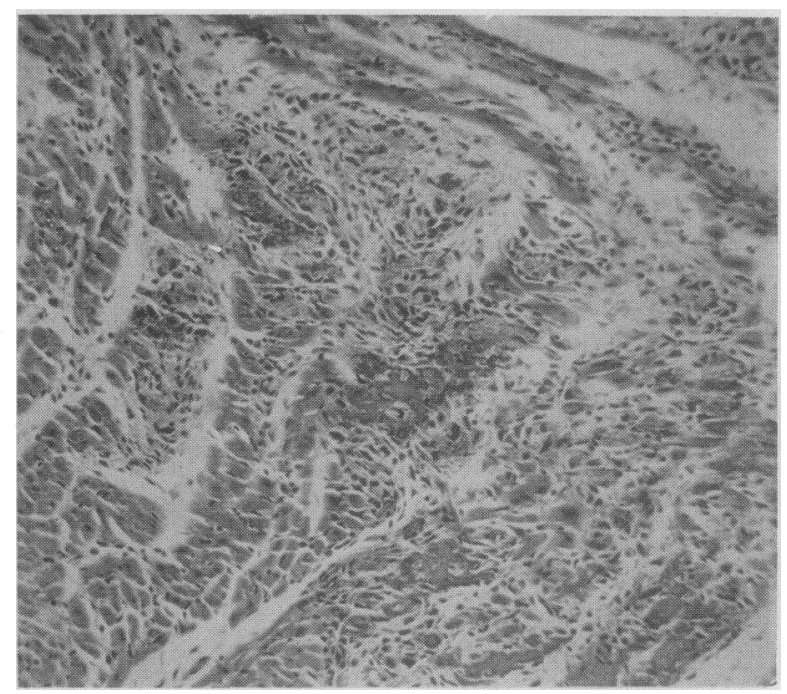

Fig. 4. Fọcal Myocardial Lesion Associated with Cortisone Alone 
TABLE II

Comparison of myocardial lesions associated with virus and cortisone*

\begin{tabular}{lccc}
\hline \hline & Virus & $\begin{array}{c}\text { Virus }+ \\
\text { Cortisone }\end{array}$ & Cortisone \\
\hline Incidence $\dagger$ & $25 \%$ & $87 \%$ & $16 \%$ \\
Distribution & Focal & Diffuse & Focal \\
Extent & + & ++++ & + \\
Cell infiltrate & ++ & ++ & + \\
Necrosis & + & ++ & ++ \\
Periarteritis & 0 & 0 & \pm \\
Valvulitis & 0 & 0 & \pm \\
Transmissibility & + & + & 0 \\
Specific neutralization & + & + & 0
\end{tabular}

* Cumulative experience of six experiments in which mice were examined 6 to 12 days after inoculation.

$\dagger$ Based on examination of 76 mice for gross lesions.

In Figure 5, reference may be made to a normal mouse myocardium.

The influence of cortisone administration on the induction of myocardial lesions in infected mice

In mice injected with virus alone, gross cardiac lesions were seldom observed until 9 to 12 days after inoculation, although infiltrative lesions with minimal necrosis (Table II) were occasionally noted by microscopy. The supplementary administration of cortisone at the same time or as late as three days after viral inoculation resulted in gross myocardial necrosis which became evident five days or more after initiation of infection. A typical experiment is presented in Table III. That gross necrosis is not related to virus concentration per se is suggested by the high titer of virus in mice without gross lesions which had received virus only although persistence of virus

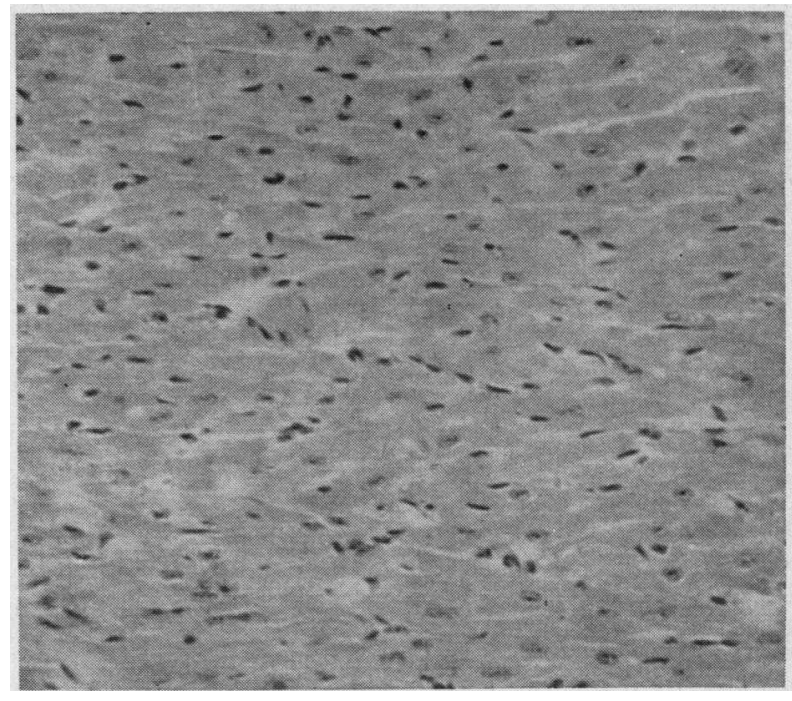

Fig. 5. Normal Mouse Myocardium

is suggested in mice given cortisone on the 5th day. Examination of Figure 6 reveals the lack of effect of cortisone on the rate of myocardial viral increase. This fact together with the observation that cortisone may induce necrosis when given near the peak of viral increase indicate that necrosis probably is not related to modification of viral multiplication.

\section{Prevention of myocardial lesions with specific viral antiserum}

The dependence of gross myocardial necrosis on the injection of virus is illustrated by the absence of lesions in mice which received a mixture of late passage 1302 virus and specific 1302 antiserum (Table IV).

TABLE III

The influence of cortisone administration on the induction of myocardial lesions

\begin{tabular}{|c|c|c|c|c|c|c|c|c|c|c|c|c|}
\hline Group 4 & $\begin{array}{c}\text { Cortisone } \\
\text { given }\end{array}$ & $\begin{array}{c}\text { Hearts } \\
\text { examined }\end{array}$ & $d / t$ & & & Irdiac & ac les & sion & score & & & $\begin{array}{c}\text { Cardiac } \\
\text { virus } \\
\text { inf. titer }\end{array}$ \\
\hline $\begin{array}{l}1 \\
2\end{array}$ & $\begin{array}{l}\text { none } \\
\text { Day } 1^{*}\end{array}$ & $\begin{array}{l}\text { Day } 5 \\
\text { Day } 5\end{array}$ & $\begin{array}{l}0 / 8 \\
3 / 8\end{array}$ & $\begin{array}{l}0 \\
3\end{array}$ & $\begin{array}{l}\mathbf{0} \\
\mathbf{3}\end{array}$ & $\begin{array}{l}\mathbf{0} \\
3\end{array}$ & $\begin{array}{l}0 \\
3\end{array}$ & $\begin{array}{l}\mathbf{0} \\
\mathbf{3}\end{array}$ & $\underline{0}$ & $\underline{0}$ & 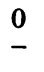 & $\begin{array}{r}6.0 \\
>6.3\end{array}$ \\
\hline $\begin{array}{l}3 \\
4\end{array}$ & $\begin{array}{l}\text { none } \\
\text { Day } 3\end{array}$ & $\begin{array}{l}\text { Day } 7 \\
\text { Day } 7\end{array}$ & $\begin{array}{l}0 / 8 \\
5 / 8\end{array}$ & $\begin{array}{l}1 \\
3\end{array}$ & $\begin{array}{l}\mathbf{0} \\
\mathbf{3}\end{array}$ & $\begin{array}{l}0 \\
3\end{array}$ & 0 & $\begin{array}{l}0 \\
-\end{array}$ & $\begin{array}{l}0 \\
-\end{array}$ & 0 & $\begin{array}{l}0 \\
-\end{array}$ & $\begin{array}{r}>6.0 \\
6.7\end{array}$ \\
\hline $\begin{array}{l}5 \\
6\end{array}$ & $\begin{array}{l}\text { none } \\
\text { Day } 5\end{array}$ & $\begin{array}{l}\text { Day } 9 \\
\text { Day } 9\end{array}$ & $\begin{array}{l}0 / 8 \\
0 / 8\end{array}$ & $\begin{array}{l}0 \\
1\end{array}$ & $\begin{array}{l}0 \\
1\end{array}$ & $\begin{array}{l}0 \\
1\end{array}$ & $\begin{array}{l}0 \\
1\end{array}$ & $\begin{array}{l}0 \\
1\end{array}$ & $\begin{array}{l}0 \\
0\end{array}$ & $\begin{array}{l}0 \\
0\end{array}$ & $\begin{array}{l}0 \\
0\end{array}$ & $\begin{array}{l}4.5 \\
5.7\end{array}$ \\
\hline
\end{tabular}

* 1 day after injection of $10^{-2}$ dilution of 18 th passage virus.

+ 3 -Lesions grossly involving 30 to 50 per cent of the myocardial surface.

1 -Lesions grossly involving 10 per cent of the myocardial surface.

0 -No grossly evident lesions. 


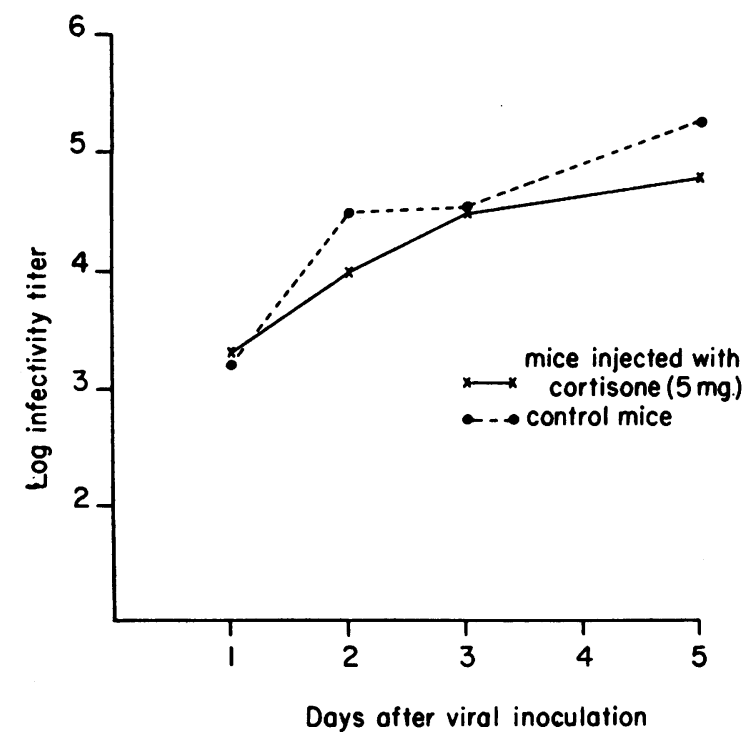

Fig. 6. Comparative InCREmental Curves of Myocardial Virus in Mice With and Without Concomitant Cortisone (19Th Passage)

Each point represents the titration end-point of pooled myocardial suspensions from five mice.

\section{Myocardial lesions in infant mice}

Neither gross nor microscopic lesions have been observed in paralyzed infant mice infected with either the infant mouse or adult mouse line of 1302 virus. Observations have not been extensive, but have been sufficient to establish that myocardial lesions must be considerably less common in infant mice than in cortisone-injected adults.

Multiplication of infant mouse 1302 virus in the hearts of adult mice not injected with cortisone

The capacity of 1302 virus to increase in the myocardium without previous adult mouse passage has been demonstrated by inoculation of untreated adult mice with infant mouse virus. Assay of 10 pooled hearts removed at the 4th day revealed an $\mathrm{LD}_{50}$ titer of $10^{-6}$.

Multiplication of virus in hearts of normal adult mice on primary isolation from human feces

An experiment was designed to determine whether clinically inapparent intracardiac multiplication of virus might occur in the absence of cortisone on direct isolation of virus from human mate- rial in adult mice. A $10^{-2}$ suspension of feces (from which a virus immunologically identical with 1302 had been previously recovered) was injected into eight adult mice. Four mice received cortisone at the time of inoculation; all were dead by the fourth day. The remaining four mice were killed on the seventh day and their hearts removed for assay of virus in cortisone-injected adult mice. The infectivity titer of $10^{-4}$ of the cardiac homogenate demonstrated the inherent capacity of this virus to propagate in cardiac tissue in the absence of exogenous cortisone.

Biological properties of 1302 virus passed in adult mice; avirulence for human and simian tissue culture

Because of the demonstrated cytopathogenicity of Group B Coxsackie viruses in tissue culture (8-10), attempts were made to titrate adult mouse 1302 virus by this convenient method. Surprisingly, cytopathogenic effects were not noted by the seventh day in either human (Hela) or Monkey (kidney) cell cultures, despite the demonstrable cytopathogenicity of the infant mouse line of the same virus (Table V). Further study of this phenomenon is illustrated in Figure 7. Two attempts to induce tissue culture cell damage with adult mouse virus were unsuccessful on initial passage. Although multiplication of virus was not demonstrable in Hela cells, extensive increase in virus not associated with visible cytopathogenic effects occurred in monkey kidney tissue. Such virus remained adult-mouse virulent but even on second passage was relatively avirulent for tissue culture (i.e., cytopathogenic in lower dilution). Even passage of adult mouse virus in infant mice

TABLE IV

Prevention of myocardial lesions with specific 1302 viral anti-serum

\begin{tabular}{|c|c|c|c|c|}
\hline \multicolumn{3}{|c|}{ Mice injected with } & \multicolumn{2}{|c|}{ Myocardial lesions } \\
\hline Virus & Serum & $\begin{array}{l}\text { Corti- } \\
\text { sone }\end{array}$ & Gross & $\begin{array}{l}\text { Micro-- } \\
\text { scopic }\end{array}$ \\
\hline $\begin{array}{l}+ \\
+ \\
0 \\
+ \\
+\end{array}$ & $\begin{array}{c}\text { Normal }^{*} \\
\text { Anti-viral } \\
0 \\
\text { Saline } \\
\text { Saline }\end{array}$ & $\begin{array}{l}+ \\
+ \\
+ \\
0 \\
+\end{array}$ & $\begin{array}{l}4 / 4 \\
0 / 4 \\
0 / 4 \\
0 / 4 \\
4 / 4\end{array}$ & $\begin{array}{l}0 / 2 \\
1 / 2\end{array}$ \\
\hline
\end{tabular}

* Pooled serum from normal mice.

$\dagger$ Two hearts from each group sectioned at three levels. 
TABLE V

Avirulence for human and simian tissue culture of virus passed in the adult mouse

\begin{tabular}{cccc}
\hline \hline & \multicolumn{3}{c}{ Virus titer in: } \\
\cline { 2 - 4 } $\begin{array}{c}\text { Virus passed } \\
\text { only in: }\end{array}$ & $\begin{array}{c}\text { Monkey } \\
\text { kidney } \\
\text { tissue } \\
\text { culture }\end{array}$ & $\begin{array}{c}\text { Hela } \\
\text { cell } \\
\text { tissue } \\
\text { culture }\end{array}$ \\
\hline $\begin{array}{c}\text { Adult mice } \\
\text { Infant mice }\end{array}$ & 4.5 & $<2.0$ & $<2.0$ \\
& 5.7 & 5.5 & 4.0 \\
\hline
\end{tabular}

did not immediately induce tissue culture pathogenicity. In contrast, 1302 infant mouse virus showed comparable titration end points in both adult mice and monkey kidney tissue. Thus, passage in the adult mouse has resulted in the emergence of virus which differs in at least one biological property from the same isolate passed in infant mice.

Comparativ'e incidence and degree of gross and microscopic myocardial lesions in mice infected in a single experiment with different strains of virus

Although the cumulative experience of the previously described experiments afforded clear evidence concerning the relative occurrence of cardiac lesions in cortisone and virus-injected mice, strict comparative assessment of lesion incidence could not be made from data available because of the differing observation periods of experiments (Table II). To determine more
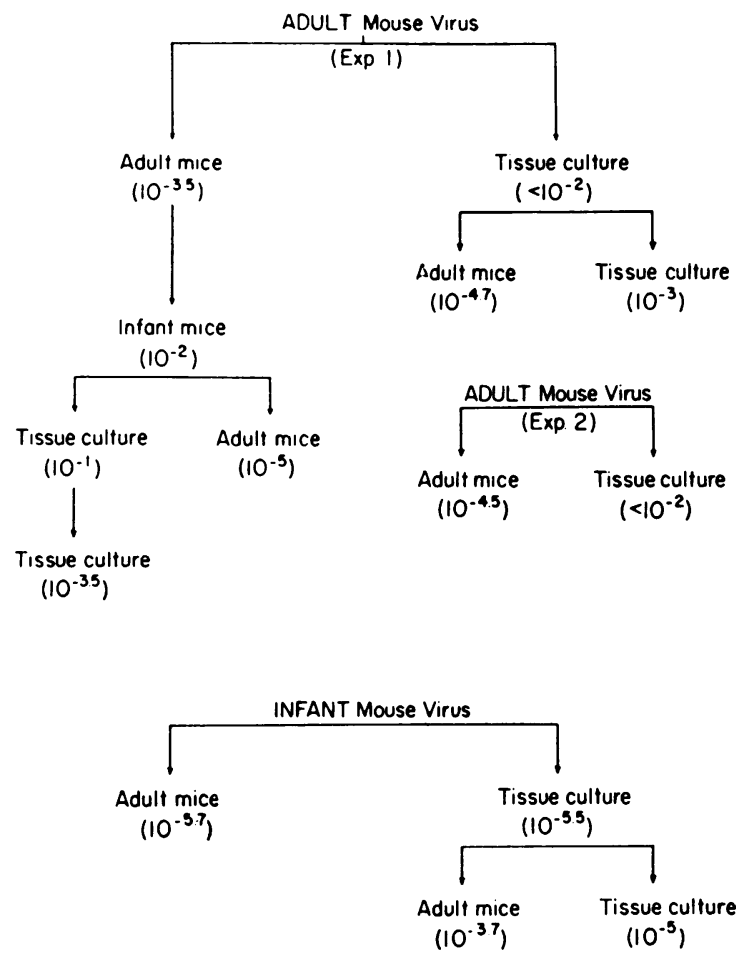

Fig. 7. Reduced Virulence of Adult Mouse Virus for Monkey Kidney Tissue Culture

Inapparent multiplication of mouse-virulent virus. Infectivity titration end points $\left(\mathrm{LD}_{50}-\right.$ mouse, and $\mathrm{TCD}_{\mathrm{so}}-$ tissue culture) are indicated parenthetically.

definitively the incidence and degree of cardiac necrosis, an experiment was devised in which 222 mice which averaged $19.5 \mathrm{Gm}$. in weight were inoculated on the same day. Subsequently, all

TABLE VI

Comparative incidence and degree of gross myocardial lesions in mice infected in a single experiment with different strains of Group $B$ Coxsackie viruses*

(Based on examination of 160 mice)

\begin{tabular}{|c|c|c|c|c|c|c|c|c|}
\hline \multirow[b]{2}{*}{ Virus } & \multirow[b]{2}{*}{ Strain } & \multirow{2}{*}{$\begin{array}{l}\text { Amt. } \\
\text { inoc. }\end{array}$} & \multirow[b]{2}{*}{ Cortisone } & \multirow[b]{2}{*}{ Mortality $\S$} & \multicolumn{4}{|c|}{ Gross lesions\| } \\
\hline & & & & & Incidence & $(\%)$ & Score & $(\%)$ \\
\hline B-3 & $1302 \mathrm{~A}$ & $2.4 \dagger$ & none & $0 / 25$ & $1 / 24$ & 4.1 & $1 / 96$ & 1.0 \\
\hline$B-3$ & $1302 \mathrm{~A}$ & 2.4 & + & $15 / 46$ & $19 / 31$ & 61.3 & $45 / 124$ & 36.2 \\
\hline B-3 & $1302 \mathrm{I}$ & 3.6 & + & $30 / 45$ & $4 / 9$ & 44.4 & $6 / 36$ & 16.7 \\
\hline$B-3$ & Dalldorf I & 3.6 & + & $7 / 25$ & $11 / 18$ & 61.0 & $20 / 72$ & 27.7 \\
\hline B-1 & Conn 5 I & 3.3 & + & $3 / 31$ & $3 / 28$ & 10.7 & $3 / 112$ & 2.6 \\
\hline Saline & - & & + & $0 / 25$ & $1 / 25$ & 4.0 & $1 / 100$ & 1.0 \\
\hline Saline & - & & none & $0 / 25$ & $0 / 25$ & 0.0 & $0 / 100$ & 0.0 \\
\hline
\end{tabular}

* A--Virus previously passed only in adult mice; $\mathrm{I}-$ Virus previously passed only in infant mice.

$\dagger$ Log of LD 20

$\mp$ Dose $-5 \mathrm{mg}$. subcutaneously.

Cumulative at the 6 th day. Number dead/total in group.

Gross lesions: Incidence - fraction of group exhibiting lesions $1+$ or greater. Score - Denominator $=$ Number of mice examined $\times 4$ when 4 is the maximum possible lesion score ( 50 per cent of myocardial surface). Numerator $=$ Cumulative actual score of group. Percentile expression makes possible comparison of scores in groups of varying size. All lesions graded on the 6th day of infection. 
TABLE VII

Incidence of microscopically evident myocardial necrosis. Microscopic examination of selected* hearts from experiment detailed in Table VI

\begin{tabular}{|c|c|c|c|c|c|c|}
\hline \multirow[b]{2}{*}{ Group } & \multirow[b]{2}{*}{ Virus } & \multirow[b]{2}{*}{ Strain } & \multirow[b]{2}{*}{ Cortisone } & \multicolumn{2}{|c|}{ Necrosis } & \multirow{2}{*}{$\begin{array}{l}\text { Perivascula } \\
\text { infiltration }\end{array}$} \\
\hline & & & & Focal & Disseminated & \\
\hline $\begin{array}{l}1 \\
2 \\
3 \\
4 \\
5 \\
6 \\
7\end{array}$ & $\begin{array}{l}\text { B-3 } \\
\text { B-3 } \\
\text { B-3 } \\
\text { B-3 } \\
\text { B-1 } \\
\text { Saline } \\
\text { Saline }\end{array}$ & $\begin{array}{l}1302 \mathrm{~A} \\
1302 \mathrm{~A} \\
1302 \text { I } \\
\text { Dalldorf I } \\
\text { Conn } 5 \text { I } \\
\quad-\end{array}$ & $\begin{array}{c}\text { None } \\
+ \\
+ \\
+ \\
+ \\
+ \\
\text { None }\end{array}$ & $\begin{array}{l}2 / 5 \dagger \\
1 / 5 \\
1 / 5 \\
1 / 5 \\
2 / 5 \\
5 / 10 \\
0 / 10\end{array}$ & $\begin{array}{l}\text { None } \\
4 / 5 \\
3 / 5 \\
4 / 5 \\
\text { None } \\
\text { None } \\
\text { None }\end{array}$ & $\begin{array}{l}\text { None } \\
\text { None } \\
\text { None } \\
\text { None } \\
\text { None } \\
2 / 10 \ddagger \\
\text { None }\end{array}$ \\
\hline
\end{tabular}

* Selected to include hearts with gross lesions in Groups 5 and 6 and without gross lesions in Group 2 . Two longitudinal sections were made of each heart; lesions in either section scored heart as positive for necrosis.

$\dagger$ Number of hearts which showed lesions out of total number examined.

I In 2 hearts which showed necrosis.

survivors were killed and examined for gross cardiac lesions six days after inoculation. The protocol of this experiment is presented in Table VI. In this experiment a number of viral strains was employed in comparable dosage in an endeavor to answer the following questions: 1) Was the cardio-necrotic effect of 1302 virus limited to this strain or could necrosis be induced by another B-3 virus (Dalldorf strain)? 2) Might the infant mouse line of 1302 virus induce cardiac necrosis comparable to that associated with the adult mouse virus? 3) Could a Group B virus of another antigenic type (B-1, Conn. 5) induce myocardial necrosis? 4) Was "spontaneous" myocardial necrosis present in control mice which received neither cortisone nor virus?

In Table VI, the incidence and extent (score) of grossly discernible lesions in mice which received differing inocula are compared. It may be seen that: 1) Administration of virus (1302 adult) alone did not kill mice and induced gross necrosis in but one heart in this short observation period; 2) with cortisone and the same virus almost one-third of the animals had succumbed by the 6th day and three-fifths of survivors exhibited gross cardiac necrosis; 3 ) the infant mouse line of 1302 virus was rapidly lethal, and did, indeed, induce gross myocardial necrosis in almost half the survivors, but this necrosis was less than half as extensive as that associated with the adult mouse virus; 4) another Group $B$, type 3 virus was similarly cardio-necrotizing with cortisone; 5) Group B, type 1 virus (Conn. 5) was associated with necrosis of minimal extent in but three of 28 survivors; 6) only one animal which re- ceived cortisone without virus incurred a gross myocardial lesion; 7) no gross lesions were observed in mice which received neither virus nor cortisone.

The possibility was considered that grossly inapparent but microscopically detectable necrosis might be present in hearts of mice in the control groups which had received cortisone alone, or neither virus nor cortisone. Ten hearts from each of these groups were sectioned longitudinally at two levels and carefully studied for histological abnormalities. Results of this study are summarized in Table VII, together with the results of an examination of five hearts from each group which received a viral inoculum. It will be seen that disseminated myocarditis predominated in animals which received B-3 viruses and cortisone. The negligible cardio-necrotic effect of B-3 virus without cortisone or of B-1 virus even supplemented with cortisone was demonstrated, paralleling the gross observations. No necrosis was demonstrated in "normal" control mice. However, microscopy revealed that 50 per cent of hearts from mice which received only cortisone had small focal areas of necrosis, associated in two instances with the perivasculitis described earlier.

The extent of necrosis noted with B-1 virus and cortisone did not exceed that associated with cortisone alone so that present evidence suggests that B-1 virus, or at least the strain employed, does not possess the marked cardiopathogenicity which characterizes the three B-3 strains studied. Although some enhancement of the myocardial pathogenicity of the 1302 strain has attended its passage in the cortisone-injected adult mouse, it 
is strongly suggested that the cardio-necrotic effect of the 1302 strain is related neither to its passage history nor to its characteristics as an isolate, but rather to the fact that it is a Group B, type 3 Coxsackie virus.

\section{DISCUSSION}

The present study has established beyond peradventure that gross myocardial necrosis may be effected by injection of cortisone into the adult mouse infected with a Coxsackie virus intrinsically capable of multiplication in the myocardium. Neither virus multiplication or cortisone administration alone induced lesions comparable in incidence or extent to those associated with administration of both virus and hormone. So too, the induction of lethal infection was dependent on the administration of cortisone. Although earlier studies have demonstrated the marked influence of cortisone on the multiplication of influenza $B$ virus $(11,12)$, significant effects on multiplication of 1302 virus have not been shown. In contrast, studies with unadapted influenza $B$ virus in mice have demonstrated the selection on passage of virus partially "dependent" on cortisone for both multiplication and pathogenicity (13). However, only the cardio-pathogenic effects of 1302 virus may be described as cortisone-dependent.

Delay of cortisone injection until the peak of influenza $B$ virus increase in eggs results in diminished inflammation and prolonged survival (14), yet opposite effects are observed with 1302 virus infection and delayed cortisone treatment. This fact buttresses other evidence that necrosis is not the result of attainment of critical concentrations of cardiac virus per se, but is more directly effected by cortisone. In view of the occurrence of myocardial lesions associated with cortisone administration alone, it appears possible that cardiac necrosis results from the synergistic influence of virus and cortisone toxicity. Thus, histologically inapparent damage resulting from the insult of either agent alone may be compounded to overt necrosis in the presence of both in combination. This hypothesis is no less attractive if cortisone-induced focal necrosis is thought to result from activation of a latent infective agent in situ. Against this possibility are the apparent non-transmissibility of the disease in the pres- ent investigation and the occurrence of cortisoneinduced damage in two species other than the mouse in skeletal muscle (15) as well as cardiac (7) sites. Skeletal muscle necrosis in the mouse has also been reported (16).

The apparent restriction of perivascular inflammation to the hearts of animals which received only cortisone is deserving of comment. It might be inferred that in some manner viral invasion "protects" the hearts of animals subjected also to cortisone administration. Such an inference might imply a viral etiology of cortisone-induced lesions and possible interference between viruses. This explanation would, of course, conflict with the hypothesis of synergistic damage advanced above, unless it were postulated that the qualitative nature of the pathologic reaction were modified by two agents in combination. A definitive answer to this question will depend on further study.

The demonstrated cardiotropicity of B-3 virus is of more than academic interest in view of the reports by Gear that a Coxsackie virus of the same antigenic type may induce fatal myocarditis in human infants $(17,18)$. It is not unreasonable to speculate on the possible conversion of the benign pleurodynia of adults to more serious, if not fatal, disease by the stimulus of endogenous or exogenous corticosteroids.

\section{SUM MARY}

1. The administration of cortisone to adult mice infected with Group B, type 3 Coxsackie virus results in extensive and disseminated myocardial necrosis.

2. The separate administration of virus or cortisone results in minimal and inconstant focal necrosis which is rarely evident on gross inspection.

3 . In the absence of exogenous cortisone virus may multiply to a high concentration in the myocardium without inducing microscopically apparent pathologic change. Multiplication of the virus is not manifestly influenced by cortisone.

4. The gross necrosis associated with injection of virus and cortisone is prevented by concomitant injection of specific viral antiserum.

5. The induction of myocardial necrosis is not dependent on a virulent adaptation of virus to the adult mouse, but may be effected with virus previously passed only in infant mice. 
6. Two different strains of Group B, type 3 virus were cardionecrotizing in contrast to the equivocal myocardial pathogenicity of a Group B, type 1 virus also capable of multiplication in the adult mouse.

7. It is postulated that the myocardial necrosis observed is not the indirect result of an influence of cortisone on viral multiplication, but rather the result of a synergistic toxicity of cortisone and an intrinsically cardiotropic virus.

\section{REFERENCES}

1. Kilbourne, E. D., and Horsfall, F. L., Jr., Lethal infection with Coxsackie virus of adult mice given cortisone. Proc. Soc. Exper. Biol. \& Med., 1951, 77, 135.

2. Sulkin, S. E., Wallis, H. C., and Donaldson, P., Differentiation of Coxsackie viruses by altering susceptibility of mice with cortisone. J. Infect. Dis., 1952, 91, 290.

3. Pappenheimer, A. M., Kunz, L. J., and Richardson, S., Passage of Coxsackie virus (Connecticut-5 strain) in adult mice with production of pancreatic disease. J. Exper. Med., 1951, 94, 45.

4. Kilbourne, E. D., Unpublished data.

5. Lenke, S. E., and Loewe, L., Cardiac lesions resembling Aschoff bodies in mice. Am. J. Path., 1941, 17, 857.

6. Gray, F. G., Spontaneous cardiac lesions in mice. Their bearing on attempts to produce experimental carditis. Am. J. Path., 1949, 25, 1215.

7. Ingle, D. J., Prestrud, M. C., and Nezamis, J. E., Effects of administering large doses of cortisone acetate to normal rats. Am. J. Physiol., 1951, 166, 171.
8. Weller, T. H., Enders, J. F., Buckingham, M., and Finn, J. J., Jr., The etiology of epidemic pleurodynia: a study of two viruses isolated from a typical outbreak. J. Immunol., 1950, 65, 337.

9. Sickles, G. M., Feorino, P., and Plager, H., Isolation and type determination of Coxsackie virus, group B, in tissue culture. Proc. Soc. Exper. Biol. \& Med., 1955, 88, 22.

10. Crowell, R. L., and Syverton, J. T., The viral range in vitro of a malignant human epithelial cell (strain Hela, Gey). IV. The cytopathogenicity of C viruses. J. Immunol., 1955, 74, 169.

11. Kilbourne, E. D., and Horsfall, F. L., Jr., Increased virus in eggs injected with cortisone. Proc. Soc. Exper. Biol. \& Med., 1951, 76, 116.

12. Kilbourne, E. D., Reactivation of non-infective virus in a cortisone-injected host. J. Exper. Med., 1955, $101,437$.

13. Kilbourne, E. D., The influence of cortisone on experimental viral infection. Differing effects of cortisone on infection of mice with influenza $A$ and $B$ viruses. To be published.

14. Kilbourne, E. D., The influence of cortisone on experimental viral infection. I. Prolongation of survival time and suppression of inflammation in chick embryos infected with influenza B virus. J. Immunol., 1955, 74, 57.

15. Ellis, J. T., Degeneration and regeneration in the muscles of cortisone-treated rabbits. Am. J. Physical Med., 1955, 34, 240.

16. Kendall, E. C., (Discussion of paper) Influence of the adrenals on carbohydrate metabolism in Conference on Metabolic Aspects of Convalescence Including Bone and Wound Healing, Reifenstein, E. C., Jr., Ed., Trans. of 10th meeting, Josiah Macy, Jr. Foundation, 1945, p. 94.

17. South African Instit. Med. Res., Myocarditis neonatorum. Ann. Report, 1952, p. 38.

18. South African Instit. Med. Res., Coxsackie viruses. Ann. Report, 1953, p. 45. 